CZU:81'342.4

https://doi.org/10.52505/filomod.2021.15.20

\title{
MODALIZAREA AUTONIMICĂ, ETEROGENEITATEA CONSTITUTIVĂ ȘI SIMPTOMELE CONVENȚIONALE - MODALITĂȚI DE SUBIECTIVARE A VOCII NARATIVE
}

\author{
Carolina GABURA \\ Universitatea de Stat din Moldova
}

Rezumat. In proza heterodiegetică și, indeosebi, cea homodiegetică, vocea narativă devine o marcă individualizatoare importantă a eului care își asumă actul narării. Ea ține de actul locutoriu, constând în afirmarea cuvintelor și propozițiilor, de faptul că limbajul e constituit din cuvinte, expresii, fraze a căror utilizare stabilește o formă de subiectivitate distinctă de ceea ce se exprimă din punct de vedere al conținuturilor. Vocea este prezentă peste tot în mod implicit, dar în orice moment poate fi evidențiată un indice ostentativ al subiectivității la care se raportează. Printre principale modalități prin care vocea etalează subiectivitatea naratorului se disting: modalizarea autonimică, eterogeneitatea constitutivă și simptomele convenționale.

Cuvinte-cheie: voce, subiectivitate, modalitate autonimică, eterogeneitate, simptom convențional.

Abstract. In heterodiegetic prose and, especially, in homodiegetic prose, the narrative voice becomes an important individualizing mark of the ego, that assumes the act of the narration. It is related to the locutionary act, consisting in the affirmation of the words and sentences, of the fact that language consists of words, expressions, phrases, whose use establishes a form of distinct subjectivity expressed from the point of view of the content. The voice is present everywhere by default, but at any time may be highlighted an ostentatious index of the subjectivity. Among the main ways in which the voice displays the subjectivity of the narrator are distinguished: autonomic modality, heterogeneity and conventional symptoms.

Keywords. voice, subjectivity, autonomic modality, heterogeneity, conventional symptoms.

Noțiunea de voce acoperă conținuturi complexe ce se referă, în special, la dimensiunile ei esențiale - corporală și naratologică. Raportată la prima sa dimensiune, vocea reprezintă ,o urmă a persoanei care vorbește, o oglindă, un index al subiectului” (Bal, 2001, p. 9), un fel de „semnătură vocală” (Barbéris, 2007, p. 11), „metafora identității noastre profunde” (Konopczynski, 2007, p. 51). In virtutea acestor determinări, metaforizate, în principal, G. Konopzinski vine cu anumite clarificări ce țin de voce ca și „,corp organic”: „Vocea e singurul instrument care ne aparține complet, este o extensie a corpului nostru, dar ea este, de asemenea, autonomă față de corp. Toți conștientizează 
faptul că vocea umană, un instrument foarte bogat, sursă a sensului în vorbire, este, de asemenea, o sursă de emoții (în două aspecte; exprimă emoții și este ea însăși o sursă de emoții)". Se mai subliniază și faptul că foneticienii insistă că majoritatea termenilor pentru a descrie vocea sunt impresioniști și că e dificil de a lucra cu valorile măsurabile ale acesteia, distingându-se totuși câțiva „parametri fonetici obiectivi” ai vocii, percepuți de ascultător, cum ar fi inălțimea, intensitatea, aspectele temporale ale diverselor elemente constitutive ale vorbirii și timbrul (Konopczynski, 2007, p. 33).

Evident, vocea unei persoane reale în funcție de aceste caracteristici denotă anumite diferențe față de cea narativă care aparține unei instanțe ficționale. În primul rând, nu are „corp organic”, căci nicidecum nu aparține autorului însuși, fiind creată de acesta ca și naratorul ori subiectul. Citându-1 pe Genette, conform căruia vocea este ,modul în care este implicată în poveste narațiunea însăși’”, Jean Kaempfer și Filippo Zanghi susțin că vocea narativă este ,atât de liniștită, încât poate părea pur și simplu tăcută. Zola, de exemplu, crede că „romancierul ar trebui să-și păstreze sentimentele” și „să afecteze pentru a dispărea complet în spatele poveștii pe care o spune". $\mathrm{Cu}$ toate acestea, chiar redusă la urme, vocea narativă nu dispare niciodată complet" (Kaempfer, Zanghi).

Într-adevăr, așa cum se întâmplă în operele cu regim narativ obiectivat, vocea naratorului rămâne a fi impersonală, lipsindu-i, de regulă, niște indici identificatorii. Însă în proza lirică, cea heterodiegetică și, îndeosebi, cea homodiegetică, vocea narativă devine o marcă individualizatoare importantă a eului care își asumă actul narării, punând în evidență, în special, rostirea lui singulară, care liricizează conținuturile expuse. Cercetătorul Laurent Perrin, studiind vocea în plan naratologic, o disociază, pe bună dreptate, de punctul de vedere: „Vocea ține de actul locutoriu, constând în afirmarea cuvintelor și propozițiilor, în timp ce punctul de vedere ține de asumarea responsabilității pentru ceea ce se spune, conținutul care i se raportează” (Perrin, 2009,p. 62) și, la fel ca Jeanne-Marie Barberis (Barbéris, 2007, p. 11), subliniază legătura strânsă ce se stabilește între voce și subiectivitate: „vocea locutorului ține de faptul că limbajul e constituit din cuvinte, expresii, fraze a căror utilizare stabilește o formă de subiectivitate distinctă de ceea ce se exprimă din punct de vedere al conținuturilor" (Perrin, 2009, p. 63). Cercetătorul mai opinează că „,vocea este prezentă peste tot în mod implicit, dar în orice moment poate fi evidențiată în mod vizibil, ca un indice ostentativ al subiectivității la care se raportează" (Perrin, 2009, p. 63). Printre principale modalități prin care vocea etalează subiectivitatea naratorului, Laurrent menționează modalizarea autonimică, eterogeneitatea și simptomele convenționale ș.a.

Modalizarea autonimică, (reflexivă) este abordată de J. Authier-Revuz în Ces mots ne viennent pas de soi: Boucles reflexives et non-coincidences du dire (Paris, 1995), abordare întemeiată pe teoria lui J. Rey-Debove și pe conceptul acestuia de conotație autonimică (Perco). Ca formă complexă a eterogeneității, numită de J. Authier-Revuz, drept arătată (hétérogénéité 
montrée), conotația autonimică rezidă în aceea că „locutorul folosește cuvinte înscrise pe firul discursului său [...], și, în același timp, le arată. Prin aceasta, postura lui de utilizator de cuvinte e dublată, momentan, de alta, cea de observator al cuvintelor, iar fragmentul astfel desemnat, marcat cu ghilimele, italice, intonație și/sau o altă formă de comentariu, obține, față de restul discursului, un statut diferit" (Authier-Revuz, 1982, p. 92). Dominique Maingueneau, sintetizând opiniile generate de concepția lui J. Revuz, afirmă că: „În limbă există și alte strategii prin care locutorul folosește o expresie arătând că ea nu este pertinentă. Ele reies din ceea ce este cunoscut sub numele de conotație autonimică, conotație care schimbă funcționarea obișnuită a opoziției dintre întrebuințtare și mențiune. Unii autori, urmându-l pe J. AuthierRevuz, preferă să vorbească despre modalizare autonimică pentru a insista pe faptul că este vorba despre urmele unei activități prin care subiectul care enunță își marchează distanțarea față de propriul său enunț: enunțătorul își dedublează, ca să spunem așa, discursul, pentru a comenta cuvântul tocmai enunțat, el produce un fel de buclă în enunțarea sa" (Maingueneau, 2008, p. 185-186). Reiese de aici că locutorul prin mijlocirea modalizării autonimice își construiește o dublă poziție: cel care formulează și, totodată, cel care comentează un element ce se referă la formularea făcută.

De notat, autonimizarea secventelor textuale contribuie, într-o anumită măsură, la liricizarea regimului narativ, întrucât „comentarile” în baza celor enunțate exprimă un plus de emoție. În fragmentul: „Când mă întorc, mă întreb dacă într-adevăr mi-e dragă, deși tot timpul, în mașină, eram întoxicat de imaginea patului nostru nupțial" (M. Eliade, Maitreyi) cuvintele evidențiate cu italice exprimă starea confuză în care se află personajul Allan, incertitudinea acestuia în legătură cu esența sentimentului trăit, cu absolutul iubirii înseși. Astfel secvența modalizată ne introduce în lumea lăuntrică a personajului, sugerând lupta interioară ce îi sfâșiie ființa. Alteori, cuvintele scrise cu italice devin marcherii unei atitudini afective duale, de admirație și ușoară ironie: „,Cu Micaela se întâmpla la fel. După o jumătate de oră, porumbița mea plecă din nou să cerceteze cutia de scrisori. Se întoarse și de astă dată cu mâna goală" (M. Drumeș, Invitație la vals) ori expresia unei vii emoții, generată de un paradox: „Câți oameni se pricep să dispară când trtebuie? Adică atunci când sunt iubiți, stimați, în plin apogeu, între suișul luminos și coborâșul sumbru? Asta e marea artă, să știi să mori frumos!” (M. Drumeș, Invitație la vals).

De regulă, ,în modalizarea autonimică, italicele sunt folosite în special în cazul cuvintelor străine pentru a insista pe anumite unităţi”" (Maingueneau, 2008, p. 192-193). Exemplele anterioare demonstrează, după cum am văzut, și excepții, deși, într-adevăr, după cum arată experiența literară (Maitreyi de M. Eliade, Adela de G. Ibrăileanu, Patul lui Procust de C. Petrescu) cuvintele cu italice, într-adevăr, desemnează cuvinte străine. Un exemplu interesant întâlnim în romanul camilpetrescian: „N-am văzut însă niciodată pe cineva mai „malencontreux" decât el. E adevărat că și eu uitam uneori că trebuie să vie, dar, de cele mai adeseori, tocmai când veneam cu prietenul meu 
acasă, îl găseam așteptându-mă" (C. Petrescu, Patul lui Procust). Adjectivul „malencontreux" folosit de naratoarea D.T., nu are funcția de a sublinia inteligența și rafinamentul ei, ci de a atribui o nuanță melodramatică trăirii și condiției lui D. și de a marca astfel un fel de distanțare față de suferința acută a acestuia, un soi de indiferență la dramele lui afective, pe care ea însăși le cauzează. E un refuz inconștient al acestui personaj feminin de a-și asuma responsabilitatea pentru durerea pricinuită, de a o împărtăși, de aici și aprecierea ușor ironică a nefericirii lui D.

Ghilimelele sunt alte mărci ale modalizării autonimice. D. Maingueneau evidențiază faptul că: „Punându-și cuvintele între ghilimele, el se mulțumește să atragă atenția co-enunțătorului asupra faptului că folosește exact cuvinte pe care le pune între ghilimele; altfel spus, le subliniază, lăsându-i co-enunțătorului grija de a înțelege de ce îi este atrasă atenția, de ce enunțătorul deschide această fantă în discursul său" (Maingeneau, 2008, p. 189). Totodată, exegetul mai subliniază că modalizarea autonimică prin ghilimele „este cea mai discretă și cea mai frecventă” (Ibidem) și că „Expresiile puse între ghilimele sau în italice sunt atât înscrise în firul enunțării, cât și distanțate de el, iar cititorul trebuie să le interpreteze sprijinindu-se pe diverse indicii de context și din situaţia de comunicare" (Ibidem). În jurnalul lui Allan din romanul Maitreyi, cuvintele din ghilimele solicită clarificarea adevăratei intenții a naratoului: „Neașteptate „explicații” cu Maitreyi. Ea a fost mai tare, astăzi. [...]. Am făgăduit Maitreyiei că vom ajunge iarăși „,prieteni”. Ce stupid! Printr-o tactică idioată am „mărturisit” o sută de minciuni care mă banalizează până la greață, am făsut „scene” etc., etc., iar ea a fost de un calm admirabil” (M. Eliade, Maitreyi). În acest caz, modalizarea autonimică indică asupra autoironiei naratorului care își persiflează manifestările emoționale, exagerate, în viziunea lui, și îl poziționează în două ipostaze: de sentimental, care participă la „explicații” și face „scene” și de lucid, care realizează o distanțare ironică de acest eu al său. Totuși, de cele mai dese ori naratorul însuși intervine cu propriile comentarii la cuvântul enunțat, de multe ori, acestea fiind și metaforizate: „Așa-zisele „palavre vânătorești” sunt minunate lucruri care tind să înfrumusețeze puțin lumea aceasta ajunsă așa de ticăloasă și așa de banală” (M. Sadoveanu, Țara de dincolo de negură); „Astăzi, de dimineață și până seara târziu, am fost „fericit”, înțelegând prin acest cuvânt tern un fluviu irațional de sentimente majore, vitale, restaurând pofta de existență și de joc” (M. Eliade, Maitreyi); „Eu știu bine că e încântată (aș spune, dar Emilia nu poate fi chiar ,încântată”, căci asta presupune o anumită fluiditate interioară" (C. Petrescu, Patul lui Procust). Alteori, comentariile enunțătorului întrețin o viziune duală asupra unei stări, sentiment: „Doamne, ce frică mi-era odinioară de lumea umbrelor! [...] Acum, această împărăţie subpământeană mi-a devenit dragă. („Dragă” e o exagerare, mai degrabă suportabilă"). 
„- Adevărat, Micaela, adevărat?

Repetam mereu ,adevărat”, dar îndărătul acestor cuvinte stăruia întrebarea nepusă: vrasăzică și tu mă iubești?” (M. Drumeș, Invitație la vals)

Din exemplele prezentate reiese că prin modalizarea autonimică vocea naratorului dezvăluie niște fațete tăinuite ale eului, îi descoperă subiectivitatea sa, participă afectiv la cele relatate. Efectul sensibilizării discursului său se obține și prin aplicarea altei forme a eterogeneității, cea constitutivă $\breve{a}^{1}$, care dă naștere polifoniei ce permite difuzarea în discurs a altei/altor voci. Este vorba, în primul rând, de așa-zisul ecou referențial al vocii, care, potrivit lui Perrin, reprezintă „ecoul uneia sau altor voci străine asociate altor situații de enunțare pe care interpretul le are în memorie ori le reconstituie mental" și are ,efectul dedublării ori hibidizării vocii locutorului în interiorul sensului" (Perrin, 2007, p. 87). În romanul Maitreyi, pe lângă vocea lui Allan se disting și ecouri ale altor voci ce transmit mesaje, comentează, apreciază. În fragmentul, „D-na Sen, îndeosebi, mă covârșește cu simpatia-i maternă. Inginerul mă numește „copilul” său” (s.n. - C. G.) (M. Eliade, Maitreyi), prin calificativul ,copilul”, se aude vocea tandră și afectuoasă a lui Sen, tatăl lui Maitreyi, care-1 tratează cu multă grijă părintească pe Allan. Alteori vocea lui Allan surprinde ecouri ale vorbirii altor personaje, cum e în exemplul „Lilu a venit să intervină, spunându-mi că „,poeta e nespus de deprimată” (M. Eliade, Maitreyi) prin care se exprimă trăirea unui personaj. Adjectivul la gradul superlativ absolut „,nespus de deprimată” accentuează starea afectivă a lui Maitreyi, dar și pe cea a vorbitorului Lilu, profund impresionat de suferința lui Maitreyi. Iar punerea în ecou a vocii lui Maitreyi induce în discursul narativ patos și gravitate care distonează cu tonul impasibil al naratorului însuși: „,La cină, Maitreyi s-a așezat lângă mine, într-o sari superbă, veche de o sută de ani. Era plânsă și tăcută; de abia a mâncat. „Mama” a înțeles totul. Mi-a mulțumit că am vorbit cu ea” (M. Eliade, Maitreyi); „În întuneric, mi-a spus că lucruri importante sunt de lămurit. Apoi, când a aflat că mă joc, că puțin îmi pasă de „sentimentele” ei, că o urăsc (mințeam), și-a pierdut calmul ei de regină (Cleopatra?) și a început să plângă. Nu am fost emoționat" (M. Eliade, Maitreyi). În romanul Adela, cuvinte-cheie din discursul Adelei-copile sunt reluate în ecou de narator, infuzându-se astfel un lirism afabil și plin de candoare: „Păpușile trebuia să le văd, pe toate, în fiecare zi să i le văd, pe toate, în fiecare zi și să le știu pe nume. Uneori, când,,avea treabă”, îmi încredința câte una s-o „păzesc”, ba chiar s-o hrănesc cu biberonul. Seara, mă ducea în toate odăile pe unde avea copii culcați prin paturi liliputane [...]; ,Fericirea ei cea mare însă era s-o ridic ,,în pod”, fericire exprimată întâi cu râsete gâlgâitoare de hulubiță mică [...].

${ }^{1}$ J. Auther-Revuz distinge heterogeneitatea arătată (hétérogénéité montrée) de cea constitutivă.Cea dintâi ,face din enunţiator mai mult decât un utilizator de cuvinte - un observator și evaluator al cuvintelor utilizate. Eterogeneitatea constitutivă face din prezența altuia drept condiție necesară a existenței subiectului și discursului său: subiectul și discursul său sunt constituite de alte surse enunțiative, constant traversate de un altul" '(Auther-Revuz, 1982, p. 91). 
Uneori, crâmpeie din discursul Adelei sunt reluate și tălmăcite cu mult afect de narator, devenind nuclee ale unor discursuri poetizate:

- A murit „petpedecul” nostru.

$[\ldots]$

„Nostru”- cuvânt emoționant, însumare într-un singur tot a existenței mele... Dar afară de pasărea moartă și de steaua din alte lumi, nimic nu mai este al nostru... Nici universul care este al tuturora!”; „Știam că ai să vii la mine. Până acum spunea „la noi”. Acest „mine” nu poate fi și el calculat. Pe lângă perversitate, ar trebui să-i acord geniu literar. Acest suav și arzător $l a$ mine... Dar..." (G. Ibrăileanu, Adela).

În romanul Ce mult te-am iubit de Z. Stancu, naratorul captează adeseori ecoul vocii tatălui său care mărturisește în repetate rânduri „-- Mărio... Mărio... ce mult te-am iubit eu pe tine, Mărio, Mărio!..." (s.n. $-C$. G.). Preluarea, pe parcursul narațiunii a acestei invocații de către narator, are, drept efect, contaminarea vocii lui cu cea a tatălui și indică solidarizarea lor față de pierderea comună, o durere comună și insuportabilă, trăită în unison, ce îi va uni pentru totdeauna. Răsunând ca un bocet cutremurător, secvența respectivă exprimă un lirism plin de amărăciune și de dor nestins ce pulsează în întreaga narațiune.

Pe de altă parte, punerea în ecou a vocii comunității, ce se face prin note sentențioase, meditative, exprimând un punct de vedere tradițional, colectiv, asupra trecerii și morții, asigură perpetuarea în narațiune a unui lirism reflexiv care, prin sobrietatea sa, cenzurează răbufnirile afective ale naratorului. Forma pronominală „noi”, în aceste cazuri, subliniază asumarea de către narator a viziunii colective și acceptarea realității vieții: „Pe toți ne așteaptă cineva în lumea de dincolo, dar nu în cer, nu în cer, ci pe pământ”; „Ce știm noi despre morți? Nimic sau aproape nimic. O să știm ceva mai mult despre morți după ce o să murim. Dar după ce o să murim n-o să le putem spune celor vii nimic din ceea ce o să auzim ca morți, nimic din ceea ce o să vedem ca morți”; „Noi oamenii - bieții de noi, bieții de noi! - avem nevoie de lacrimi cum avem nevoie de apă, cum avem nevoie de aer, de pâine. $\mathrm{Nu}$, nu e adevărat. $N$-avem nevoie de lacrimi. Avem nevoie mai curând de zâmbete, de cât mai multe zâmbete".

În romanul Descult de Z. Stancu, intervine o voce anonimă, care este cea a conștiinței colective, deținătoare a unei filosofii specifice asupra vieții umane. Împletindu-se, vocea naratorului și cea anonimă generează dialoguri cu un spectru tematic variat, ce mențin în narațiune un lirism de esență interogativă:

„- Eşti schimbător ca vremea, Darie.

- Sunt! Și ce poftești dumneata dacă sunt? Te superi pe vreme că e schimbătoare?

$-N u$.

- Atunci, cu mine ce ai? 
- Tu nu ești vreme. Tu ești om, Darie. Și asta e altceva.

O fi".

Alteori, vocea naratorului lasă să întrevadă prezența unui glas lăuntric, care verbalizează conținuturi sufletești de profunzime, lirismul subiacent al formației lui interioare:

„- Cum de ce? Mai are vreun rost să te întrebi, Darie? Ție îți plac caii pentru că pe cal, tu, beteagul, te simți om întreg, îndemânatic și ager ca un șoim.

- Bine, dar de ce îmi place apa râurilor, a lacurilor și a mărilor?

$[\ldots]$

- Ție, Darie, apele râurilor și apele lacurilor, apele fluviilor și apele mărilor îți sunt dragi pentru că ție, schilodule, în apă îți piere sfiala și îți piere stânjeneala. În apă mișcările tale sunt sprintee, vioaie. Iți piere și tristețea. În schimb, te cotropoește bucuria blajină a vieții, și toată făptura ta strâmbă, slabă, slută și urâtă cântă ca o vioară vrăjită...".

Alături de modalitatea autonimică și eterogeneitate, simptomele convenționale reprezintă niște indicatori ce scot în evidență proprietăţi specifice ale vocii. În această ordine de idei, Laurrent Perrin susține că în virtutea unei concepții conform căreia sensul lingvistic al expresiilor este redat, în primul rând, de ceea ce este spus (în plan propoziţional și conceptual), vocea reprezintă o funcție pur retorică asociată utilizării de semne. Ea mai degrabă relevă ,gesticulația locuţionară” despre care vorbește Berrendonner, decât semnificația lingvistică, sensul codificat al expresiei. Dar, precizează mai departe savantul, ,sensul lingvistic al expresiilor nu se reduce la ceea ce ele spun. Anumite expresii au de asemenea (sau, uneori, în principal,) funcția de a certifica, în mod convențional, prin cod lingvistic, anumite proprietăţi ale enunțării lor, adică ale vocii locutorului ce le enunță. Vorbim despre simptomul convențional asociat vocii. Anumite expresii codifică forța lor de simptom" (Perrin, 2009, p. 63). Printre acestea, Perrin semnalează expresiile performative ori modale, interjecțiile și alte formule. Primele, în mare măsură, asigură tonalitatea emotivă a vocii naratorului sau a personajelor în virtutea posibilităţii lor de asociere a diferitor simptome convenţionale. Se știe, expresiile performative se referă la actele de vorbire teoretizate de J. L. Austin și J. Searle. Teoria actelor de vorbire se bazează pe echivalența dintre a spune şi a face, definită de J. L. Austin drept ,a spune ceva este, în sens deplin, a face ceva. Acest set include producerea anumitor sunete, producerea anumitor cuvinte în diferite construcții și producerea lor cu o anumită „semnificație” [...]. Numesc (botez) actul "de a spune ceva" - în acest sens normal deplin performarea unui act locutoriu" (Austin, 2005, p. 46). După cum afirmă Elena Constantinovici, „Teza centrală a acestei teorii de filozofie a limbajului este că nici cuvântul, nici propoziția, nici fraza nu reprezintă unitatea minimală de comunicare, ci producerea acestora în momentul în care se realizează actul de vorbire" (Constantinovici, p. 44). Cercetătoarea Alina Pătrunjel subliniază că, potrivit teoriei actelor de vorbire, ,esenţa semnificației unui enunț nu 
se reduce doar la condiția lui de adevăr, ci implică și luarea în considerare a scopului cu care acesta este folosit în actul concret de comunicare" (Pătrunjel, 2018, p. 134). Iar cercetătorul Alexandru Boboc susține că „Teoria ,actelor de limbaj" ridică problema dependenței semnificației nu de simpla utilizare în limbă, ci de contextul acțional al rostirii, de faptul rostirii, acesta din urmă nefiind simplă spunere, zicere, enunțare a ceva" (apud Constantinovici). În funcție de acest context și de acest fapt un enunț se performează, adică i se adaugă o forță ilocuționară specifică situației de comunicare.

Expresiile performative aduc un plus de informație despre intențiile și reacțiile emoționale ale celui care vorbește, devenind simptome convenționale asociate vocii lui, și, la rândul lor, îi subiectivează și, totodată, liricizează expunerea. Printre acestea, se remarcă, în primul rând, actele de vorbire asertive, utilizate atât în vorbirea naratorului, cât și a personajelor. Să urmărim un exemplu:

„1.- Ai rămas văduvă, Mario...

- 2. Am rămas, mamă...

- 3. Și-ai venit să-mi cazi în vatră cu plozii...

- 4. Unde era să mă duc?...

- 5. Să fi așteptat la casa ta...

- 6. Casa mea! N-aveam nici de unele. A băut tot, înainte de a muri. Numai juncanii mi-au rămas" (Z. Stancu, Ce mult te-am iubit)

Asertivele evaluative $(1,3)$ din această secvență folosite de personajul mama constată, pe de o parte, noua condiție a fiicei, iar, pe de altă parte, servesc drept simptom convențional al unei forme de nemulțumire, cauzată de situația când fiica este nevoită să revină acasă. Reacția emoțională a mamei este susținută și de enunțul 5 , care reprezintă un act de vorbire directiv, prin forma de conjunctiv trecut al verbului, ce atenuează impresia de ordin pe care-1 trădează. Replicile fetei redate prin acte de vorbire de tip întrebare (4) și asertiv (6), servesc drept simptome convenționale a deznădejdii de care este copleșită și care este subliniată de exclamația „Casa mea!”.

În următorul exemplu, asertivele evaluative asociază vocii naratorului, ce se adresează unui tu imaginar, un ton de încântare, susținut, în plan sintactic de prezența semnelor exclamative ce subliniază, alături de elementele figurative, firea expansivă a eului: „Alteori vântul se repede asupra ta ca un vrăjmaș. Te pălmuie și te biciuie.

Și dacă nu te ții bine pe picioare, te trântește în țărână. Ce dulce e vântul primăverii!

Da, e dulce vântul primăverii!

Și eu i-am cunoscut dulceața" (Z. Stancu, Desculț).

În romanul Ce mult te-am iubit de Z. Stancu asertivele evaluative devin, de asemenea, simptome convenționale ale unei stări de regret, suscitată de conștientizarea, de către personajul-narator, a imposibilității de a întoarce timpul înapoi pentru a-și exprima înalta sa considerație mamei: „Și eu am 
iubit-o pe mama. Mult, mult de tot am iubit-o eu pe mama, însă n-am apucat să-i spun. A murit, a murit de-adevăratelea și eu n-am apucat să-i spun c-o iubesc, n-am apucat să-i mulțumesc că m-a adus pe lume".

Tonalităţile lirice ale vocii naratorului sunt susținute și de actele de vorbire interogative, care, deseori cuprind întrebări retorice, trăsătura lor esențială, fiind emotivitatea. De aceea prezența acestora în discursul naratorului corespunde unor simptome conventionale ale unor dileme, nedumeriri, confuzii, în raport cu sine și cu lumea, ce generează un lirism plin de patos, cum e în proza lui M. Drumeş, Z. Stancu: „Ce se întâmplase? Se ferea de mine, mă ocolea? Îi era teamă să-mi întâlnească privirile? Încă mai lupta cu ea? Tot nu-și dădea seama că se isprăvise cu împotrivirea ei?” (M. Drumeș, Invitație la vals); „Mama își doarme somnul de veci și eu trăiesc. E bine că trăiesc? E rău că trăiesc? Nu e nici bine, nu e nici rău...nici bine, nici rău... Nu e în nici un fel. Trăiesc. Și atât. Nu e destul? E totul”. (Z. Stancu, Ce mult te-am iubit) De asemenea, în proza lui Z. Stancua, actele de vorbire interogative servesc drept pretext pentru reflecții: „Ați rămas lângă cişmea noaptea? Apa curge mai vie, mai repede parcă, gâlgâiala ei pare plină de bucurie. Dacă o încerci, bagi de seamă că are alt gust - gust de miez de pământ.

Aţi adormit vreodată pe câmp noaptea? Dorm pe câmp noaptea, înfăşurat în cojoc ori împătură. E tare pământul! E tare. Când îl calci cu piciorul, e tare. Noaptea, când te-ntinzi pe ierburi să dormi, şi ierburile se culcă sub tine supuse, pământul e moale, mătăsos, de parcă ar fi făcut din puf de nori străvezii" (Z. Stancu, Desculț).Tot ele devin suportul unor dialoguri interioare ce întrețin pe largi parcursuri lirismul interogativ și, datorită intonației ascendente cu care sunt rostite, adaugă intensitate vocii narative:

„Dar sunt om.

Şi în om se aprinde o flacără.

Cine o aprinde?

De ce o aprinde?

Spune-mi: te poţi mulţumi cu iarba?

Alergi prin ea cu picioarele desculţe.

Şi picioarele ţi se udă de rouă.

Când eşti copil, asta îţi place.

Dar te poţi hrăni oare cu iarbă?

Nici iarba nu e a ta.

Şi ce minunată este pădurea! Nimeni n-o ştie mai bine ca mine. I-am cunoscut toţi copacii şi toate păsările.

Crezi că seaman un copac cu alt copac?

Crezi că seamănă o ramură cu altă ramură?

Crezi că seamănă o frunză cu altă frunză?

Te înşeli.

Mai curând seamănă un om cu alt om decât un copac cu alt copac, o ramură cu altă ramură, o frunză cu altă frunză" (Z. Stancu, Desculț). 
Actele de vorbire de tip cerere de asemenea asociază vocii eului diverse simptome convenționale:

\section{,- Taci cu mama, taci cu mama, taci cu mama!}

$\mathrm{Nu}$ tace Evanghelina. Nu tace Ion. Scutecele mereu trebuie spălate, schimbate, uscate. Mama are ochi frumoşi, coade lungi, galbene ca ovăzul copt, mijloc subţire.Văduvă la şaptesprezece ani!...

- Taci cu mama, taci cu mama, taci cu mama!..." (Z. Stancu, Desculț). În această secvență, actele directive subliniate devin simptome convenționale ale unei alerte interioare înăbușite de personaj prin acest îndemn matern: „Taci cu mama" menit să calmeze nu numai copilul, ci și să potolească neliniștea din interiorul ei. Actele directive alternează deseori cu cele promisive, iar, datorită tonului solemn cu care sunt rostite, asociază vocii gravitate:

„- Când ai să te faci mare, Darie, să mergi să vezi munţii şi să te-ntorci acasă să ne spui şi nouă, cum sunt...

- Da, mamă, am să merg să văd munţii.

- Şi-apoi să te duci să vezi marea şi să te-ntorci acasă să ne spui şi nouă cum e...

- Da, mamă, am să merg să văd marea"(Z. Stancu, Desculț).

Iar actele de vorbire de tip invitație asociază uneori vocii interioare a eului căldură și încântare: „Auzeam de pe acum un glas care mă chema, care mă momea:

- Vino, Darie... Vino şi vezi minunata cetate...” (Z. Stancu, Desculț).

Alături de expresiile performative, interjecțiile asociază vocii narative diverse simptome convenționale, ce trimit la reacțiile emotive ale eului. Se știe că interjecțiile au funcția de a exprima senzații, sentimente, emoții, caracterizându-se printr-o intonație specifică de tip exclamativ. Apariția acestora în vorbirea personajelor ori a naratorului emfatizează, adaugă o nuanță patetică discursului lor, semnalând participarea lor afectivă la cele întâmplate. De notat faptul că, spre deosebire de poeți, prozatorii recurg mai rar la virtuțile interjecțiilor de a emfatiza și sensibiliza discursul. Le utilizează mai des L. Blaga, Z. Stancu, M. Drumeș, M. Sadoveanu. De multe ori, una și aceeași interjecție la același autor ori la autori diferiți devine simptomul convențional al unor stări diferite: de nedumerire „Ah, Doamne! Răspunse Leonte, ,parcă n-am fi fost martorii tăi” (L. Blaga, Luntrea lui Caron); de mirare „Ah, ah. Ce ți-s obișnuințele imaginației! " (L. Blaga, Luntrea lui Caron); de fascinație „Ah, draga de ea! Cât mă iubea!” (M. Drumeș, Invitație la vals); de nemulțumire „Ah, casierul se mișca așa de greoi, ca într-un film au relanti” (M. Drumeș, Invitație la vals); de regret „Ah, Doamne, ce mare scriitor ar fi ieșit din mine dacă tata mi-ar fi transmis puternicul și coloratul lui dar de a povesti (Z. Stancu, Ce mult te-am iubit); deseori de emotivitate afișată ce descoperă un sentimentalism artificios ,Ah, adu-mi aminte să trecem pe la bijutier” (M. Drumeș, Invitație la vals); „Ah, uitasem de ziua asta...” (M. Drumeș, Invitație la vals); „Ah, ce leneșă sunt! Aștepți de mult? (G. Ibrăileanu, Adela). Interjecțiile, după cum am subliniat, schimbă intonația 
vocii într-una exclmativă și, indiferent de nuanța afectivă ce o concretizează, scoate în evidență, în primul rând, starea de afect a vorbitorului: „Simion? Oh, bietul Simion! S-a întors, dar nu mai era morar", mă lămurește doamna preoteasă” (L. Blaga, Luntrea lui Caron); „Oh, dar lucrurile nu mai sunt așa de simple” (M. Eliade, Maitreyi); „O!...doamne, Doamne!...nu cumva și mâinile mamei sunt la fel?"'(Z. Stancu, Ce mult te-am iubit)

Or, modalitatea autonimică, eterogeneitatea constitutivă și simptomele convenționale devin importante surse de subiectivare a vocii narative și, nu în ultimul rând, de liricizare a regimului narativ instituit de narator.

\section{Referințe bibliografice:}

1. AUTHIER-REVUZ, Jacqueline. Hétérogénéité montrée et hétérogénéité constitutive: éléments pour une approche de 1 , autredans le disco. În: Documentation et Recherche en Linguistique Allemande Vincennes, 1982, nr. 26, p. 91-151. [online] Disponibil: https://www.persee.fr/doc/drlav_0754-9296_1982_num_26_1 978\#drlav_0754-9296_1982_num_26_1_T1_0091_0000 [citat 14.08.2021]

2. AUSTIN, John Langshaw. Cüm să faci lucruri cu vorbe. Pitești, 2005.

3. BAL, Mieke. Voix/Voie narrative - la voix métaphorée. In: Cahiers de Narratologie, 2001, nr. 10.1, p. 9-36.

4. BARBERIS, Jeanne-Marie. Présentation. In: Cahiers de praxématique, 2007, nr. 49 , p. $7-22$.

5. CONSTANTINOVICI, Elena. Teoria actelor de vorbire - constituire și evoluție. [online] Disponibil: https://ibn.idsi. md/sites/default/files/imag_file/44-50.pdf [citat 12.07.2021]

6. CORLĂTEANU, Nicolae, ZAGAEVSCHI, Vladimir. Fonetica, Chişinău, 1993.

7. KAEMPFER, Jean, ZANGHI, Filippo. La voix narrative. [online] Disponibil: https://www.unige.ch/lettres/framo/en seignements/methodes/vnarrative/vnintegr.html [citat 17.07.2021]

8. KONOPCZYNSKI, Gabrielle. La voix: monosupport ou multisupport? In: Cahiers de praxématique. 2007, nr. 49, p. 33-56.

9. MAINGUENEAU, Dominique. Lingvistica pentru textul literar. Iași, 2008.

10. PĂTRUNJEL, Alina. Modele de descriere a actelor de vorbire în lingvistica pragmatică. În: Akademos, 2018, nr.4, p. 133-136.

11. PERKO, Gregor. Modalisation autonymiquie et dinamisme communicatif. [online] Disponibil: https://www.eer.cz/f iles/2012-1/2012-1-20-Perko.pdf [citat 16.07.2021]

12. PERRIN, Laurent. Aspects de la voix du locuteur à l'intérieur du sens. In: Cahiers de praxématique, 2007, nr. 49, p. 79-101.

13. PERRIN, Laurent. La voix et le point de vue comme formes poliphonique externe. In: Langue française. 2009/4, nr. 164, p. 61-79. 